\title{
On the Mode of Feeding of the Hermit-crab, Eupagurus Bernhardus, and some other Decapoda. \\ By
}

J. H. Orton, D.Sc.,

Chief Naturalist at the Plymouth Laboratory.

CONTENTS.

Introduction ${ }^{\circ}$

Experiments with the hermit-crab, E. Bernhardus, and oysters (O. edulis) $\quad$. $\quad . \quad 999$

Observations and experiments on the mode of feeding of E. Bernhardus . . $\quad .910$

On the function of the mouth parts, and some unusual features of the gut, of $E$. Bernhardus

On the mode of feeding and food of some other Decapoda and the function of the third maxillipedes

Some relationships of the hermit-erab with its commensals.

Summary . . . . . . . . . . . . . . . . . . . . . . . 920

References . . . . . . . . . . . . . . .

\section{INTRODUCTION.}

WHilst working on the oyster beds in the Fal Estuary, hermit-crabs, Eupagurus Bernhardus, were being frequently taken in the dredge-hauls and systematically killed, and the question was raised whether this hermit-crab might be in any way responsible for the shortage of oysters. I replied that I did not know, and that it seemed unlikely that the hermitcrab would be a serious enemy of the oyster; but as these crabs are numerous on the beds the matter might be important, and it would probably not be difficult to obtain definite data on the subject. The following observations were made in attempts to obtain the required information.

\section{Experiments with the Hermit-crab (E. Bernhardus) AND Oysters (O. EDULIS).}

On December 21st, 1926, a sample of hermit-crabs was forwarded from the oyster beds, and of the twenty sent eleven recovered after arrival on December 23rd. It was considered advisable to examine individuals from the beds where oysters occur, since $E$. Bernhardus exists in numbers off Plymouth (Allen, 1899), and in other situations remote from oyster beds, where hermit-crabs might not have the same habits, particularly 
with regard to bivalves and oysters. The hermit-crabs were placed in well-aerated water and allowed several days to recover from the effects of the journey before a number of young oysters, $1_{2} \frac{1}{2}$ to 2 inches long, were added to the dish in which the hermit-crabs were placed. Later fresh batches of hermit-crabs and some smaller oysters, with thin shells only about 1 inch to $1 \frac{1}{1}$ inches long, were obtained. At no time have the hermitcrabs been found to show any inimical interest in the oysters with which they were kept, and in view of what has been observed of their mode of feeding, it is highly probable that hermit-crabs are in no sense harmful to healthy oysters, which have attained a size of about 1 inch or more, although like most crabs they would, no doubt, attack weak or dying oysters. This hermit-crab is, however, so clumsy, owing to the impediment of the shell, which it carries, that it would probably be beaten by other crabs, especially Carcinus manas, which is common on certain parts of the Fal Estuary beds, in a hunt for a weakly oyster.

$E$. Bernhardus attempts to break barnacles and tubicolous worms (e.g. Pomatoceros) from stones and shells, and in this way will no doubt kill inadvertently a small proportion of very young oysters.

It is possible that $E$. Bernhardus may also obtain oyster larvæ, at the time these settle, by scraping objects with its third maxillipedes; but various Amphipods, worms, and other animals are probably greater enemies of the oyster at this stage of existence than is the hermit-crab.

\section{Observations and Experiments on the Mode of Feeding of}

\section{E. BERNHARDUS.}

Whilst observing the hermit-crabs, it was noticed that individuals scraped various objects in the dish with their third maxillipedes, and as Porcellana longicornis is known to use the similar appendages for catching food-particles (Gosse, see Potts, 1916), it was suspected that the hermitcrab obtained food in a similar way. To test this suspicion bunches of Ascidiella aspersa, which had accumulated much sediment and extraneous growth, were added to the dish, and the scraping operation was found to be repeated. On confirmation of this fact it was decided to add sediment to the dish to make it resemble the bottom on the oyster bed, which is mainly muddy or muddy gravel. A sediment usually rich in micro-organisms was obtained from walings exposed at low water at the Great Western Docks and made to form a layer on the bottom of the dish.

As a result of this arrangement, an additional act of feeding could be seen. The hermit-crabs now scraped the bottom of the dish--with its covering of sediment-with its smaller claw, and passed on the products of the scraping to the third maxillipedes, whose hairs were used like a brush 
to transfer the collected particles towards the mouth. This movement is carried out automatically for long periods, and if arrested can be started by adding fresh material or the juices of fresh Pecten meat to the water. When the captured particles reach the smaller mouth parts they are sifted in some way, since a cloud of rejected material is borne forwards and upwards in the stream of water emerging from the gill-chamber. From these actions it seemed clear that the hermit-crab was feeding on material obtained by sifting and selecting from sedimentary deposits. In order to obtain more definite information a hermit-crab was isolated for a period without food in a clean bottle with circulating water, and to this water was added, after the period of isolation, brushings of the brown incrustations found on stones and other objects on the foreshore. This brown material consists of a feltwork of small filamentous algæ and chain and free diatoms, with Vorticellids, Acineterians, and other microorganisms. After leaving the hermit-crab in the bottle with this material overnight, the animal was anæsthetised and the contents of the gut examined. The stomach and first part of the intestine were found to contain quantities of the diatoms and algal threads and other material similar in mass to that added to the bottle, but already in a partly digested state.

To test whether the feeding action observed in the Laboratory occurred on the oyster beds, the stomachs and intestines of fourteen individuals, sent to the Laboratory in February, were examined.

In the gut of these hermit-crabs was found a collection of detritic and food material similar to that which may be found in the oyster or Crepidulæ (Orton, 1912) with, in addition, microscopic bits of brown and green algæ, in one case also algal ova, fragments of microscopic shells, crustaceans, and polychætes. The material in the gut which resembles that found in oysters and Crepidula consists of microscopic sand-grains, sponge spicules, diatoms, foraminifera, algal threads, and polychæte and crustacean bristles, but the two latter kinds of material may have been derived in the case of the hermit-crab from captured organisms.

The food found in the stomachs and intestines of hermit-crabs during the winter months is probably small in amount in comparison with what may be taken during the spring and summer, and observations will need to be continued throughout the year to obtain adequate information.

It is clear, however, that the hermit-crab obtains its food largely by scooping up loose detritic material from the sea-bottom and objects on the sea-bottom, and selecting therefrom the organic constituents. In this way are obtained small polychætes, small crustaceans, small algæ, foraminifera, diatoms, and other micro-organisms. The relative importance of this kind of food-material in comparison with that derived from larger food-organisms cannot be estimated without seasonal examination 
of gut contents of a considerable number of individuals, a research which might not even, on completion, give the desired information (see the work on the food of the American lobster (Heriick, 1911). The writer, however, holds the view that when all the information relating to feeding in the hermit-crab is considered, there remains little doubt that the food obtained by the small pincer and third maxillipede constitutes the main diet. As the hermit-crab can obtain food without its large claws, it is interesting to note that the loss of the latter is not so serious a matter as it would be if the claws were essential for feeding.

Hunt (1925) examined stomachs of E. Bernhardus and E. Prideauxii from the Plymouth trawling grounds, and remarks that they "feed on small lamellibranchs (Venus, Cultellus, etc.), echinoderms (Echinocyamus, small Echinocardium, ophiuroids), crustaceans (amphipods, crangonids, smaller pagurids), and polychætes (Polynoidæ, Nephthys, Goniada, Terebellidæ, Pectinaria). Detritus and sand are found in their stomachs, but only in quantity that might have been swallowed along with their prey." From this description it would appear that E. Prideauxii feeds in the same way as $E$. Bernhardus, but that the size of the foodorganisms at the time Hunt examined the stomachs was rather larger than microfauna, and indicates the probability, as suggested above, of seasonal variations in the kind of food capturable by means of the small chelæ and third maxillipedes.

It is well known that Eupagurus Bernhardus will eat fish-meat of any kind, and Jackson (1913); in his valuable memoir on this animal, makes the following remarks under the heading of food: "The hermit-crab (E. Bernhardus) is an omnivorous feeder. In its early youth it follows the cannibalistic instincts of other zoeas, but the adult seems to be purely a scavenger. It will accept almost any animal or vegetable food. The left chela (the small one) is almost invariably used for carrying the food to the foot-jaws, and it also aids them in tearing the morsels to suitable shreds. It may be observed very frequently tossing sand with the same appendage between the mouth parts, and letting the grains drop as it rubs them. * There is no doubt M. T. Thompson is right in thinking that the diatoms and foraminifera which are found in the alimentary canal come from this source." It is clear from Jackson's remarks that he had observed this hermit-crab's habit of passing on sedimentary material to the mouth parts with its smaller (left) chela, but would seem not to have realised the full significance of the act; possibly he observed animals in dishes containing only few sand-grains, and was therefore unable to note how the animal behaved in its natural environment, that is, on a bottom containing a fair to a considerable amount of fine sand, sediment, or mud. As Eupagurus Bernhardus belongs to that

\footnotetext{
* The italics have been inserted by the writer.
} 
section of the bottom fauna known as epifauna, it has unfortunately been generally omitted from quantitative surveys carried out recently by naturalists with the Petersen grab, but Allen (1899) made an estimate of the relative frequency of species on and about the 30 -fathom line near Plymouth, and remarks that " this hermit-crab is present on grounds of all kinds, though it is most abundant on the sand and on the gravel and sand grounds where the fauna is generally rich." He records the species as most common on grounds II and III with respectively $95 \cdot 8$ per cent fine sand with 1.9 per cent silt, and 82.7 per cent fine sand with $1 \cdot 1$ per cent silt. On the estuarine grounds in the Fal Estuary the nature of the bottom where this hermit-crab occurs in abundance varies from muddy to a muddy gravel, in which the percentage of silt would everywhere be very much higher than on the grounds off Plymouth. These facts indicate that the microfauna on a fine sandy ground may be, as is indicated by Hunt (1925), as great as on an estuarine muddy ground, but it is not impossible that other food-factors may govern the distribution of the hermit-crab. It may be remarked in passing that as this hermit-crab is an important member of those animals which subsist on food-material derived from the sea-bottom, its omission from bottom-communities affords an example of the artificiality of these so-called communities.

\section{On the Function of the Mouth Parts, and some Unusual Features in the Gut, of E. Bernhardus.}

When it was found that the stomach and intestines of hermit-crabs taken from the oyster beds contained a large amount of food-material picked up from the sea-bed, the question arose to what extent the mouth parts might be modified for this purpose. Jackson (l.c.) shows the mouth parts to be normal in form, but comparison with the similar appendages in Carcinus or Portunus shows that they are relatively feeble. The mouth parts in a hermit-crab are indeed not adapted in the same way as those of the typical crabs mentioned for cutting up and ingesting such food as fish-meat. In order to obtain some expression of this difference, E. Bernhardus, Carcinus manas, and Portunus puber were fed with pieces of squid-meat of approximately the same size. The hermit-crabs could only nibble tiny pieces at a time from their food-masses, while the crabs cut up theirs rapidly. At the end of an hour and a quarter, the hermit-crabs had still one-fourth to one-third of their food left, while both Carcinus and Portunus had eaten and swallowed theirs in four to eleven minutes. Similar time-relations were found with regard to softer food, such as the gills of Pecten or the visceral mass of Tapes. There can be no doubt that these observations show that although E. Bernhardus 
can eat portions of fish-meat, its mouth parts are not adapted to a regular diet on this kind of food. It is further significant that all hermit-crabs (Anomura) differ from all crabs (Brachyura) in not having the third maxillipedes broadened out to form an operculum over the inner mouth parts (Calman, 1909), and an important function of the opercular maxillipedes in crabs is to retain food-masses under pressure in contact with the cutting inner mouth parts, so that the food can be readily and quickly sub-divided and ingested. It is therefore a reasonable conclusion that the normal food of hermit-crabs and other Anomura is likely to differ from that of the true crabs.

In view of the suggestions made later and the possibility of correlating in detail the structure with the function of the third maxillipede, it is worth while to give here Calman's review of the variations in form of this appendage in Decapoda. He states that "The third maxillipede may, in the Natantia, even exceed in length the next succeeding pair of appendages. The exopodite and basipodite are almost always connected by an immovable articulation. In the Caridea the ischiopodite is quite coalesced with the meropodite, and the dactylopodite is obsolete or coalesced with the preceding segment. A serrate ridge or 'cresta dentata' is commonly present on the third segment, but no endites are developed from the first and second segments. Among the. Brachyura the third maxillipedes become greatly modified to form an operculum to the buccal frame and entirely lose their pediform character. The ischiopodite and meropodite become broad plates and the terminal three segments are often hidden behind the meropodite. The peduncle of the exopodite may also be expanded and share in forming the operculum. Its terminal flagellum is either folded out of sight or may be entirely lost. The epipodite forms a long curved blade in most Brachyura."

With regard to the ossicles in the stomach of $E$. Bernhardus, Jackson (l.c.) notes that "The cardiac ossicle is far more slender than is usual, and is bow-shaped; the pterocardiac ossicles are also slender. . . . The lateral teeth are unusually massive and are prolonged backwards into strongly pectinated ridges. The summit of the cardiopyloric valve also bears a ridge of great blunt setæ like a comb." The slender nature of some of the ossicles gives a hint that the need for these organs for the manipulation of ingested food is not the same in this crustacean as in such a form as Cancer, while the occurrence of pectinate lateral teeth and the development of setæ is in harmony with a mode of feeding on the smaller organisms in sedimentary material. Potts (1916) shows that an extreme reduction of the gastric ossicles occurs in the plankton-feeding crabs, Hapalocarcinus and Cryptochirus.

The form of the gut in $E$. Bernhardus is interésting in that Jackson has found (l.c.) the achitinous-and absorptive-portion of the mid-gut to 
be unusually long. This fact would lead one to infer that the food ingested is either of a detritic or vegetable nature in conformity with the general occurrence of a relatively long intestine in animals which feed on the organic contents of detritus or on vegetable matter. But it would appear that this conclusion can hardly be permitted in the present state of our knowledge of the natural food and physiology of digestion in crustaceans. The mid-gut in E. Bernhardus gives off long-paired anterior cæca and a long unpaired posterior cæcum. These facts are again suggestive of an effort to increase the absorptive area of the intestine in correlation with the nature of the food, but the interpretation is not at present justifiable from the occurrence as noted by Jackson (l.c.) of a very short achitinous mid-gut in $E$. longicarpus, an American hermit-crab, which M. T. Thompson (1904) found to feed in the same way as E. Bernhardus. Moreover, the lobster (Homarus) and the Norway lobster, Nephrops norvegicus, both have a long mid-gut, and both these animals are believed to be carnivorous according to Herrick (1911) and Yonge (1923). The natural food of these forms is, however, very difficult to determine, and it will be well worth while to review their feeding habits in the light of the information which is accumulating with regard to the use of the third maxillipedes as a food-collecting organ. Herrick examined stomachs of $H$. Americanus preserved during a period of seven months (December to June), and makes the following remarks: "A considerable number of these stomachs were empty; more than half contained remnants of recently devoured fish, a mass of scales and bones, mixed with fragments of the indigestible parts of other organisms. In many cases it was quite evident that the bait of traps formed the only food found in their stomachs." ... "The stomachs examined contained remnants of the following organisms placed in the order of their relative abundance: fish (procured independently of the traps) ; crustacea, embracing chiefly isopods and decapods; mollusca, consisting largely of small univalves; algæ; echinoderms and hydroids. . . . In the large lobster found at the Vinal Haven Islands I have seen the muddy bottom scored in all directions--the work of lobsters in their search for clams. . . . As a fisherman remarked, if you put lobsters in a pound and do not feed them, they will soon turn over the bottom as effectually as it could be done with a plough." * From these observations the information regarding the natural food of the American lobster must be regarded as unsatisfactory, and as our information regarding the English lobster (H. vulgaris) is similar to that of its American relative, there is reason to believe that a special study of the food and mode of feeding of these and allied forms, especially Palinurus, the crawfish, would be profitable. It would be easy to overlook the possibility of small organisms serving

\footnotetext{
* The italies have been inserted by the writer.
} 
as food in the case of these large animals. In any event a physiological explanation of the occurrence of a large achitinous mid-gut in some forms and a small one in others is required.

With regard to the histology of the gut and its appendages in $E$. Bernhardus, Jackson (l.c.) notes that "The histology of the digestive gland differs somewhat from that described by Pearson (1908) in Cancer. The so-called 'fat-cells' are never scattered round the lumen, but bulge out (like a typhlosole) from one point only at a time. It seems doubtful whether the division into 'fat' and 'ferment' cells can be justified, and whether the fat-cells are not to be considered only as ferment-cells. The lining of the mid-gut is characteristic. The cells are columnar with large nuclei and considerable contents of fatty matter." From Jackson's observations there is an indication that the physiology of digestion in two such forms as Eupagurus and a truly carnivorous ally, such as Cancer probably is, is different, and in conjunction with that in Porcellana longicornis and Pinnotheres pisum 으, would afford an interesting comparative study.

On the Mode of Feeding and Food of some other Decapoda and the Function of the Third Maxillipedes.

Now that it is established that $E$. Bernhardus obtains micro-organisms for food by means mainly of its third maxillipedes, it is worth while reviewing and, indeed, investigating the mode of feeding in all the forms closely allied to Eupagurus. With regard to E. longicarpus, the American hermit-crab, M. T. Thompson (1904) remarks: "Like many other Decapods, Eupagurus longicarpus is crepuscular, and during the day a majority of individuals remain buried in the sand or congregated in the shade. They are omnivorous and must glean very closely, as they pick up bits of gravel or detritus from the bottom and brush them over between the maxillipedes. They also toss sand-usually with the smaller chelipeds only - to the mouth parts, brush it between them, and let the grains fall again in a continuous stream. Probably it is in this manner that they obtain the diatoms and foraminifera, which are found in the stomach and intestine. But although the food is thus very largely diatomaceous, no sort of vegetable or animal matter is refused." It is seen, therefore, that M. T. Thompson found that $E$. longicarpus feeds in the same way as E. Bernhardus. The experiment described on p. 910 with regard to $E$. Bernhardus, if repeated on $E$. longicarpus, would apparently speedily prove that the latter does obtain its micro-organisms by the intermediary of the third maxillipede. It has been noted that other organisms than diatoms are obtained by this mode of feeding, and some of these may have greater total food value than diatoms; for instance, foraminifera and microscopic bivalves, polychætes, and crustacea. 
It is thus clear that two hermit-crabs obtain a large portion of their food from micro-organisms and others slightly larger, and there can be no doubt that allied species will be found similar in this respect. It is known that Porcellana platycheles also uses its third maxillipede for obtaining food (Borradaile, 1921), and the writer has observed that Porcellana longicornis uses the same organs, which when extended are as long or rather longer than the cephalothorax, like whips or lacrosse rackets, throwing out the left and right one alternately, for catching suspended particles, which are removed from the basket-like organs by a scooping action of one of the inner mouth parts; Hunt (1925) has observed that the stomach contents of this crab-and other crustacea, which feed similarly, such as cirripedes and an amphipod - " consist of an assortment of detritus and micro-organisms quite comparable to that found in the ciliary feeding suspension-feeders." Hapalocarcinus, like Porcellana, uses its third maxillipedes for collecting plankton, which provides the sole form of food (Potts, 1916). It is also well known that the females of the pea-crab, Pinnotheres pisum - and no doubt other pea-crabs-feed on the food caught in the mucus strings of its hosts, such as Mycilus, Cardium, and others (Orton, 1921); Pinnotheres thus takes the same kind of food second-hand, as Porcellana longicornis obtains at first-hand. Hunt's valuable investigations on the food of the bottom fauna (1925) indicate, as might now be anticipated, that many decapoda may be found to obtain their food by using the third maxillipedes either for collecting organisms in suspension, or in the sediments on the seabottom. For example, Hunt shows that the burrowing forms, Callianassa and Gebia, had " nothing but a mixture of sand, mud and detritus with the usual associated small organisms " in the stomachs of the specimens examined, and other burrowing forms are probably largely similar in their habits. In the stomach of Galathea nexa Hunt found small crustaceans, small polychætes and detritus, with foraminifera, diatoms, copepod eggs, peridinians, a congeries of organisms very similar to that occurring in the gut of hermit-crabs from the oyster beds. This species of Galathea, and no doubt also its related species and genera, probably feeds with its third maxillipedes in the same - or a similar-manner as Porcellana.

In addition to these forms, the sluggish crabs, Hyas, Pisa, Dromia, Inachus, Macropodia, and possibly Maia, may be found to obtain a major portion of their food by means of their third maxillipedes after the manner described above for hermit-crabs and other Anomura. It will be interesting to learn in what way the third maxillipede is modified throughout the Decapoda to subserve different functions, but there can now be no doubt that its form is directly correlated with its function, and that the difference in the form of this organ in crabs and other 
Decapoda, especially the old group, Anomura, denotes a fundamental difference in the mode of feeding. The modifications of this appendage in Hapalocarcinus, Macropodia, and Porcellana, figured by Potts (1916, Fig. 6), and the curious anomaly in the structure and disposition of the same organs in Pinnotheres, described by the same writer, support the conclusion that the form of this organ is closely correlated with its function. The degree to which these appendages and the related mouth parts are modifiable in response to change in function, even in a crab, is well brought out by Potts (l.c.), who shows that the mouth parts of Hapalocarcinus and Cryptochirus are modified to such a degree as to resemble those of a Branchiopod.

\section{Some Relationships of the Hermit-crab with its Commensals.}

The details of the mode of feeding of the hermit-crab, as described in the preceding pages, enable the relationships of the commensals, Hydractinia, Calliactis (Sagartia), and perhaps Nereis fucata, to be better understood.

It has been noted that the hermit-crab is almost continuously, or at least very frequently, scooping up portions of the sediment on the seabottom with such an inefficient scooper as the small claw, and sifting the sedimentary material in the outgoing respiratory current. As a result of these actions a small cloud of the bottom sediment containing microorganisms is frequently produced in the region surrounding the hermitcrab. If the hermit-crab is facing the tidal current, this cloud will be carried around the inhabited shell and the polyps of Hydractinia situated thereon will receive a gratuitous supply of food-material and be thereby enabled to grow and multiply into large colonies on the shell. When the hermit-crab is not facing the tidal current, or in situations where there is no current, the sedimentary material may frequently be carried away from the region of the shell, or a portion only be brought in contact with the hydroids on the shell according to variable complex conditions, but there can be no doubt that Hydractinia obtains a greater supply of food-material as a result of the hermit-crab's habit of sifting bottom deposits than it would if the food of the latter were entirely large organisms. Hydractinia will, however, obtain food also from the sediment which is disturbed and lifted up in the water merely as a result of the hermit-crab dragging its shell over the bottom, and a greater amount of food would be obtained in this way on bottoms where the micro-fauna is easily disturbed, as, for example, on muddy grounds and the softer deposits. It is interesting that Allen (l.c.) found Fydractinia only sparingly associated with E. Bernhardus on fine sand, whereas the hydroid 
is commonly present on the muddy beds in the Fal Estuary, but other conditions may also govern the distribution of this hydroid.

The frequent scraping of the sea-bottom by the hermit-crab along with the movement of the inhabited shell will certainly disturb organisms. such as polychætes, small crabs and similar forms ; and as the anemone, Calliactis (Sagartia) parasitica, which is frequently carried on the shell, has the habit of pressing its disc on to the surface of the bottom (Sinel, 1906 ; and Orton, 1922), the anemone must in this way obtain its main supply of food. The anemone will also obtain additional food from that scattered by the hermit-crab in its inefficient rending apart of large masses of food-material, such as a weak or dying mollusc or small crab. Further, as the hermit-crab can only ingest food of the latter kind slowly, it must frequently happen that when the hermit-crab has accumulated between the maxillipedes all the food it can carry, the remainder will become the share of the anemone or anemones. A hermit-crab with its foot-jaws crammed with food will sometimes drag about the remainder of the unattacked food by means of its big claw. In these circumstances a quick turn by the hermit-crab, such as no doubt frequently occurs owing to other crabs smelling the food, and hunting for it, would often bring the spare food within reach of the anemone, which at once seizes tenaciously morsels of this kind. The possibility that the hermit-crab may definitely and willingly share a portion of its food, when it has gorged its jaws with enough to eat for several hours, maý now be considered not unreasonable (Orton, 1922). In this connexion a little further light is perhaps thrown on the observed act of Nereis fucata, the worm frequently present in the shell inhabited by the hermit-crab, taking pieces of food out of the foot-jaws of its partner. If the hermit-crab has captured even a moderately large supply of food in mass, it will probably seldom be able to eat it all itself, owing to its slow rate of eating and the probability of other crabs soon finding and capturing the spare food which it cannot adequately defend. The loss of one portion of food, if others are available, would not therefore necessarily be a net loss, and the worm might obtain a portion of food without detriment to the hermit-crab. It is unlikely, however, that the true relations of this worm to the hermit-crab will be properly understood until a close study is made of their mutual behaviour during feeding, and the gut contents of the worm, when freshly caught, have been determined. The only probable advantage to the hermit-crab from its association with the worm is that of having the water in the shell renewed by the rhythmical wave-like motion of the body of the worm, but it is also possible that the worm may assist the hermit-crab by removing from the mouth parts of the latter undesirable food which may inadvertently have been attacked. 


\section{SUMMARY.}

The hermit-crab, Eupagurus Bernhardus, is common in the oyster beds in the upper part of the Fal Estuary, and experiments indicate, while observations and experiments on the mode of feeding virtually prove, that these hermit-crabs do not harm healthy small oysters one inch or more in length, and the larger oysters, but that spat less than one inch may occasionally be damaged or eaten by hermit-crabs picking with their claws indiscriminately at growths on shells and stones.

$E$. Bernhardus obtains food largely by its small claw and third maxillipedes, and may at certain periods of the year feed mainly on microorganisms, and at others on macroscopic, but mainly tiny living organisms which have been disturbed and captured in the deposits on the seabottom. Food can be obtained by the use of the third maxillipedes alone.

The mouth parts of $E$. Bernhardus are not adapted for rapid ingestion of the meats of animals in bulk, and the gastric mill is less strongly developed than in the carnivorous crabs ; these facts, along with certain features of the gut, indicate morphological and anatomical modification correlated with the food and mode of feeding.

E. longicarpus feeds in the same way as E. Bernhardus, and allied species may obtain food similarly.

Some Decapoda are now known to obtain food mainly by use of the third maxillipedes, as Porcellana, Hapalocarcinus, and some subsist entirely on planktonic food-material as Porcellana longicornis, Pinnotheres pisum , and it is probable that a large number of other Decapoda obtain small or microscopic organisms as food mainly by use of the third maxillipedes. The structure of the third maxillipede in all Decapoda is probably definitely correlated with its function in feeding actions.

Some additional points in the relations of the hermit-crab with its commensals are better understood when the mode of feeding of the former is considered.

\section{REFERENCES.}

Allen, E. J. 1899. On the Fauna and Bottom Deposits near the Thirtyfathom Line from the Eddystone Grounds to Start Point. Journ. Mar. Biol. Assoc., N.S., V, 1899.

Sined, J. 1906. An Outline of the Natural History of our Shores.

Thompson, M. T. 1904. The Metamorphoses of the Hermit-Crab, No. 4. Proc. Boston Soc. Nat. Hist., XXXI, 1904.

Pearson, J. 1908. Cancer. L.M.B.C. Memoir, XVI, 1908, London.

Calman, W. T. 1909. A Treatise on Zoology. Edited by Sir E. Ray Lankester, Part VII, Appendiculata (Third Fascicle, Crustacea). 
Herrick, F. H. 1911. Natural History of the American Lobster. Bull. U.S. Bureau Fisheries, Washington, XXIX, Doc. No. 747.

ORton, J. H. 1912. The Mode of Feeding of Crepidula, etc. Journ. Mar. Biol. Assoc., N.S., IX, p. 445.

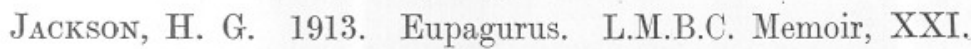

Poтts, F. A. 1916. Hapalocarcinus, the Gall-forming Crab, with some Notes on the related Genus, Cryptothirus. Pubn. No. 212, Carnegie Institution of Washington (1915).

Borradatle, L. A. 1921. Note on the Mouth Parts of certain Decapod Crustaceans. Proc. Camb. Phil. Soc., XX.

Orton, J. H. 1921. Mode of Feeding and Sex-phenomena in the PeaCrab, Pinnotheres pisum. Nature, Vol. 106, p. 533.

ORton, J. H. 1922. The Relationship between the common HermitCrab (Eupagurus Bernhardus) and the Anemone (Sagartia parasitica). Nature, Vol. 110, p. 735.

Yonge, C. M. 1924. Studies on the Comparative Physiology of Digestion. II. The Mechanism of Feeding, Digestion, and Assimilation in: Nephrops norvegicus. Brit. Journ. Exper. Biol., Vol. 1.

Hunt, 0. D. 1925. The Food of the Bottom Fauna of the Plymouth Fishing Grounds. Journ. Mar. Biol. Assoc., N.S., XIII, p. 560. 
